\title{
Examining the Determinants of Facebook Continuance Intention and Addiction: The Moderating Role of Satisfaction and Trust
}

\author{
Mahmoud Maqableh ${ }^{1}{ }^{\mathbb{D}}$, Zaid Obeidat ${ }^{1}$, Ahmad Obeidat $^{1}$, Mais Jaradat ${ }^{2}$, Mahmood Hussain Shah $^{3}$ \\ and Ra'ed Masa'deh ${ }^{1, *(1)}$
}

check for

updates

Citation: Maqableh, M.; Obeidat, Z.; Obeidat, A.; Jaradat, M.; Shah, M.H.;

Masa'deh, R. Examining the

Determinants of Facebook

Continuance Intention and Addiction The Moderating Role of Satisfaction and Trust. Informatics 2021, 8, 62. https://doi.org/10.3390/

informatics 8030062

Academic Editor: Olga Kurasova

Received: 17 July 2021

Accepted: 13 September 2021

Published: 21 September 2021

Publisher's Note: MDPI stays neutral with regard to jurisdictional claims in published maps and institutional affiliations.

Copyright: (c) 2021 by the authors. Licensee MDPI, Basel, Switzerland. This article is an open access article distributed under the terms and conditions of the Creative Commons Attribution (CC BY) license (https:/ / creativecommons.org/licenses/by/ $4.0 /)$.
1 School of Business, University of Jordan, Amman 11942, Jordan; maqableh@ju.edu.jo (M.M.); z.obeidat@ju.edu.jo (Z.O.); a.obeidat@ju.edu.jo (A.O.)

2 Department of Civil Engineering, Engineering Project Management, School of Engineering, University of Jordan, Amman 11942, Jordan; maisjaradat@gmail.com

3 Newcastle Business School, Northumberia University, Newcastle NE1 8ST, UK; mahmood.shah@northumbria.ac.uk

* Correspondence: r.masadeh@ju.edu.jo

\begin{abstract}
Social media addiction has undergone a remarkable transformation among regular users, but limited research has been conducted on exploring the antecedents of addiction. The purpose of this study is to investigate the relationship between continuance intention and addiction. Moreover, it investigates the moderating role of satisfaction and trust on the relationship between continuance intention and addiction. The developed conceptual model suggests that continuance intention is the antecedent of addiction, while satisfaction and trust act as moderators between continuance intention and addiction. The antecedents of continuance intention are emotional, informational, social, and hedonic values. A survey was conducted to collect data from 572 voluntary participants, and the analysis was performed using SPSS and AMOS. The statistical result showed the effects of emotional, informational, and hedonic values on Facebook use continuance intention, but the effect of social value was not supported. Results also confirmed a significant effect of continuance intention on Facebook addiction. Additionally, it confirmed the moderating role of satisfaction on the impact of continuance intention on Facebook addiction, but the moderating role of trust was not supported. The results of this study provide insight for Facebook users, managers, and policymakers regarding treatment and intervention for Facebook addiction. It discusses several theoretical and practical implications. In this research, we proposed a new model based on extending the associations between perceived value and continuance behaviours theory.
\end{abstract}

Keywords: Facebook addiction; continuance intention; perceived values; satisfaction; social networks

\section{Introduction}

As a result of recent technological developments, the Internet has become a fundamental instrument in online communications and transactions. In the current digital environment, web-based services have become very popular [1]. Included in these services are the online social networking services (SNSs), which have become a universal concept and a new pattern of communication. Thus, these platforms (e.g., Twitter, YouTube, Snapchat, Instagram, and Facebook) have transformed the methods through which people and firms interact [2]. The most popular social network platform is Facebook, due to the perceived values provided to its users [3]. It was initially designed to help students connect, but they also use it to communicate, learn, and socialise with friends, family, and others [4]. Nowadays, the number of daily active users is 1.88 billion, and the number of monthly active users is 2.27 billion [5]. The growing popularity of this platform has led people to spend between 5 and $8 \mathrm{~h}$ a day on it [6]. 
Some scholars argue for the positive contribution of Facebook use to social interaction, e.g., connectivity, access, and improved productivity [7], while other scholars argue against it, citing its dark sides, including excessive use and addiction. The excessive use of Facebook often results in several negative consequences, including distraction, poor health, lower self-esteem, and addiction [8]. Facebook addiction has often been referred to as a psychological reliance on the use of Facebook in a way that hinders other important activities for the person, thereby yielding negative consequences [7]. This led researchers to propose that excessive use of Facebook and other online platforms resembles a type of addiction due to the number of negative consequences it generates, which most often accompany a classic case of addiction, e.g., withdrawal, deterioration, conflict, and mood swings [9-13].

In recent years, increasing research has focused on social networks' platform-related issues [14]; social networks' social functions [15,16]; social networks' entertainment functions [17,18]; factors affecting use intentions [19]; and stickiness [1,20]. Two main concerns for social networks users are the lack of sufficient trust and satisfaction. Therefore, many research studies examined the satisfaction and trust in the context of continuance intention of social networks [21-23]. Other research streams examined the consequences of addiction to these platforms on an individual's well-being and his/her work outcomes, such as anxiety, insomnia, and turnover $[7,22]$. Others focused on its antecedents, such as personality, values, self-esteem, loneliness, relationship building, and social activities [24]. Despite the insightful findings that these studies provided, limited attention was given to the influence of trust and the user's perceived values of social media addiction, i.e., Facebook [25]. Additionally, limited attention has been paid to studying the impact of continuance intention and addiction to social networks. Our study compares the impact of social media perceived values on the continuance intention of users and consequently to Facebook addiction. Considering that most social media platforms, such as Facebook, now provide shopping, chatting, instant messaging, and gaming facilities, the influence of these attributes on consumer intention to use and addiction needs to be further examined [19]. Therefore, examining the impact of these factors on social media addiction in this research precludes an effort to examine this unexplored area in the literature.

Consequently, based on a Facebook setting, this study proposes a new model based on extending the associations between perceived value and continuance behaviours. Thus, this research applied and validated value theory and literature related to integration and interactivity in the Facebook continuance intention context with the following aims:

(1) Inspect the influence of users' perceived values on the continuance intention;

(2) Examine the correlation between the continuance intention and addiction; and finally

(3) Investigate the moderating role of satisfaction and trust on the relationship between continuous intention and Facebook users' addiction.

There are several inferences gained from the findings of this study in terms of theory and practice. Theoretically, this research extends important resolutions to the different reported gaps in the literature. Furthermore, this study explains the impact of users' values on continuance intention and addiction behaviour on Facebook. This is of importance to researchers in this area. In terms of managerial implications, this study enhances the understanding of the factors that can reduce social media continuance intention and addiction. This is of great significance to professionals and policymakers interested in addressing this phenomenon and appropriately devising measures, techniques, and policies to enhance the effective consumption of social media applications in general and Facebook in particular.

\section{Literature Review and Hypotheses Development}

Existing research on social media addiction has been categorised into three key categories or themes:

- The first stream of research focuses on the antecedents to the continuous intention of SNS. These studies identify factors such as habits, message richness, message synchronicity [26], personality, self-esteem, loneliness, relationship building, social 
activities [24], service, relationship quality [27], social norms and attitudes [28], flow experience [27], and perceived values [1,25,29-31].

- In terms of addiction, different factors were identified, such as security [6], psychological traits [32], self-esteem factors [9], loneliness [24], age [33], and relationship building [24]. In terms of addiction consequences, the literature examined the effect of addiction on academic performance [2,34], anxiety, insomnia, turnover, performance [7], and internet addiction [12].

- The third and final theme in the literature focuses on the types of online addictions. This theme recognised internet addiction [35], internet gaming disorders [36,37], smartphone addiction [38], and Facebook and social media addiction [39,40].

Finally, by examining this literature, it can be observed that existing studies analysed the antecedents of continuous intention and addiction separately (see Table 1). Therefore, we examine this gap by investigating the association between continuous intention and addiction to Facebook along with the moderating factors affecting it.

Table 1. Some recent research based on continuance behaviour, perceived values, and addiction.

\begin{tabular}{|c|c|c|}
\hline Literature & Variables & Moderators \\
\hline [1] & Epistemic value, social value, hedonic value, stickiness & Trust \\
\hline [25] & $\begin{array}{l}\text { Network externalities, social interaction ties, social value, information } \\
\text { value, emotional value, hedonic value, continuance intention }\end{array}$ & - \\
\hline [30] & Innovativeness, hedonic value, utilitarian value, continuance intention & - \\
\hline [31] & $\begin{array}{c}\text { Perceived integration, perceived interactivity, perceived values, } \\
\text { continuance intention }\end{array}$ & - \\
\hline [7] & SNS addiction, tasks, position emotions, employee performance & - \\
\hline [20] & $\begin{array}{c}\text { Discontinuous usage intention, SNS satisfaction, SNS exhaustion, social } \\
\text { overload, receiving social support }\end{array}$ & - \\
\hline [40] & Neuroticism, extraversion, social media addiction & - \\
\hline [41] & Relative advantage, perceived value, continuance intention & Compatibility \\
\hline Our Proposed Model & $\begin{array}{c}\text { Social value, information value, emotional value, hedonic value, } \\
\text { continuance intention }\end{array}$ & $\begin{array}{l}\text { Trust and } \\
\text { Satisfaction }\end{array}$ \\
\hline
\end{tabular}

\subsection{Perceived Values and Continuance Intention}

The perceived value refers to the assessment or estimation made by consumers for the benefits they will acquire from an offering, minus the actual costs of doing so [42]. Overall, perceived values have many dimensions, including utilitarian and hedonic values from the user's motivation perspective $[43,44]$ and intrinsic and extrinsic values from a goal orientation perspective, which also includes economic, social, hedonic, and altruistic dimensions within it [25]. Other research viewed values as dimensions of enjoyment or usefulness [45] or in terms of epistemic, functional, and conditional values [46]. This research examines the influence of four main values (i.e., emotional, informational, social, and hedonic) on continuous intention. While the consequence of users' perceived values on the continuance intention is already established [47], how different forms of these values impact the continuance intention to use social media platforms is yet unclear [25]. Extrinsic values, the first value of our value set (i.e., social value), refers to the observed usefulness of the platform to users in building and maintaining relationships as well as representing themselves and acquiring social approval [19].

Generally, Facebook is considered a social platform for maintaining social relationships between its members [1]. Consequently, people use Facebook to interact, gain social recognition from peers, and display their inner selves [48]. With the communication tools that it provides (e.g., pictures, videos, games, messages etc.), Facebook presents its members with different means to satisfy their social needs. Here, informational value refers to the advantage of obtaining information from the user in the network that is useful [25]. Additionally, Facebook also allows users to look for information and news that enhances their ability and skills [47]. 
In terms of intrinsic values, the emotional value relates to the positive effective relief or satisfaction gained from the support of the online community [49]. Facebook tools, such as status updates and comments, help users express themselves emotionally and gain emotional support from their contacts [25]. The hedonic value, on the other hand, refers to the pleasure and enjoyment obtained from online interactions and activities [25]. Facebook provides browser games for entertainment [17], which coaxes many users to join the platforms for the games and the entertainment value they provide [1]. In 2018, [31] investigated the link between the perceived values on mobile GSM (a government microblogging service) continuance intention. The research aimed to understand the factor that affected the continuance use of mobile GSM in China by focusing on perceived values. The results of the analysis disclosed that hedonic, social, and informational values in turn positively influenced mobile continuance. In contrast, emotional value was not significant on mobile GSM continuance.

Our study proposes that these values will significantly influence the Facebook continuance intention to use. This claim is supported by previous findings in the literature; for example, [47] positively linked perceived values and behavioural intention. Additionally, hedonic and utilitarian values were found to impact the word-of-mouth intentions of social media networks [29]. Positive links were also found between these four values and the WeChat (a popular Chinese social media platform) continuance intention to use. Kupfer et al. (2016) [50] and Zhang et al. (2017) [25] also found positive links between social and hedonic values and the continuance usage intention of SNS. Consequently, we can generally deduce that these four perceived values would positively affect Facebook continuance intention to use. Thus, we get the following hypotheses:

Hypothesis 1 (H1). Emotional value positively influences Facebook continuance intention.

Hypothesis 2 (H2). Informational value positively influences Facebook continuance intention.

Hypothesis 3 (H3). Social value positively influences Facebook continuance intention.

Hypothesis 4 (H4). Hedonic value positively influences Facebook continuance intention.

\subsection{Continuance Intention and Facebook Addiction}

Continuance intention refers to the Facebook user's initial decision to reuse the website [47]. Hence, Facebook addiction refers to the excessive use of Facebook due to being psychologically reliant on its use in a way that somewhat hinders other essential actions that the user could perform and, in the process, yields negative results [7]. There are about 350 million Facebook users between 16 and 25 years old showing Facebook addiction syndrome [51]. Overall, previous literature has mainly examined the concept of continuance intention as a dependent variable $[1,25,31,52,53]$. However, we will examine its relationship with Facebook addiction. Generally, numerous theories and findings have established the relationship between behavioural intention and actual behaviour [54-56]. Consequently, if the continuance intention of Facebook use is present, the user will continue to do so, thereby increasing the chances of addiction to the website. Furthermore, previous studies found that when a certain behaviour is exhibited and the person is willing to do it again, future behaviour becomes an automatic, aligned response [57]. Therefore, the more a person uses social media to communicate with others, the more likely it is to become a habit and lead to addiction [55].

There are many research studies examined the relationship between continuance intention and addiction [22,58]. In [58], the study examined the impact of Internet continuance intention and addiction. The study results showed that continuance intention has a positive impact on Internet addiction. Some other research examined the impact of users' levels of addiction on users' continuance intention to use WeChat [22]. The analysis resulted showed that SNS addiction positively affects the determents of continuance intention. Additionally, many research studies have been conducted to more effectively understand the variables 
that affect social media addiction [40]. A research study identified and examined Internet addiction and higher rates of Facebook addiction [59]. In addition, Facebook addiction is related to higher levels of loneliness and social anxiety [40]. A research study found individuals with more online social ties tended to experience higher levels of Facebook addiction [60]. Another study found that social anxiety has a positive relationship with social media addiction amongst young adults in China [61].

Following the same logic, we propose that the Facebook continuance intention resulting from perceived values will increase Facebook addiction. Thus, this study is the first study that investigates the relationship between continuance intention and the addiction gap. Generally, this factor was found to strongly influence the association between online purchase intention and actual behaviour [58,62]. Thus:

Hypothesis 5 (H5). Continuance intention positively influences Facebook addiction.

\subsection{The Moderating Role of Satisfaction and Trust}

Satisfaction refers to user's judgments about how well that service provides a pleasurable level of fulfilment $[63,64]$, while trust refers to the tendency to believe in others and their posted articles on a website [1,65]. Several studies reported the important role of satisfaction and trust as determinants of behaviour and behavioural intention $[23,41,66,67]$. Other studies have examined the role of satisfaction as full mediation or partial mediation in the relationship between quality dimensions and behaviour intentions $[68,69]$ in consumer behaviour literature [70]. In addition, the moderating role of trust has been examined in electronic commerce as having a direct impact on intentions [71] and in the relationship between perceived values and social network consumer stickiness [1].

Recently, the moderating effects of satisfaction and trust on behaviour intention and behaviour were examined in organic food consumers in Australia [72]. The results confirmed that satisfaction and trust are positively and significantly likely to lessen the gap between intention behaviour and consumers' behaviour. Facebook users' satisfaction and trust may affect the relationship between continuance intention and addiction. In the literature, there is no evidence reflecting the moderating roles of satisfaction and trust on continuance intention and social networks addiction relationships. This study fills the research gap by analysing the moderating role of satisfaction between the relationship of continuance intention and Facebook users' addictions. This study is the first such study to examine the moderating effects of satisfaction and trust on the relationship between continuance intention and addiction. Therefore, the last two hypotheses are proposed to confirm the moderating role of satisfaction and trust on the relationship between Facebook users' continuance intention and addiction.

Hypothesis 6 (H6). Satisfaction would have a moderator effect on the impact of continuance intention on Facebook addiction.

Hypothesis 7 (H7). Trust would have a moderator effect on the impact of continuance intention on Facebook addiction.

\section{Research Model and Hypotheses Testing}

As we mentioned before, in this research, we propose a new model based on extending the associations between perceived value and the continuance behaviours theory by investigating the relationship between continuance intention and addiction gap. Moreover, it investigates the moderating role of satisfaction and trust on the relationship between continuance intention and the addiction gap. Thus, the current study suggests that the hedonic, emotional, informational, and social values represent important antecedents to Facebook's continuance intention and, in turn, affect Facebook addiction directly, as seen in Figure 1. 


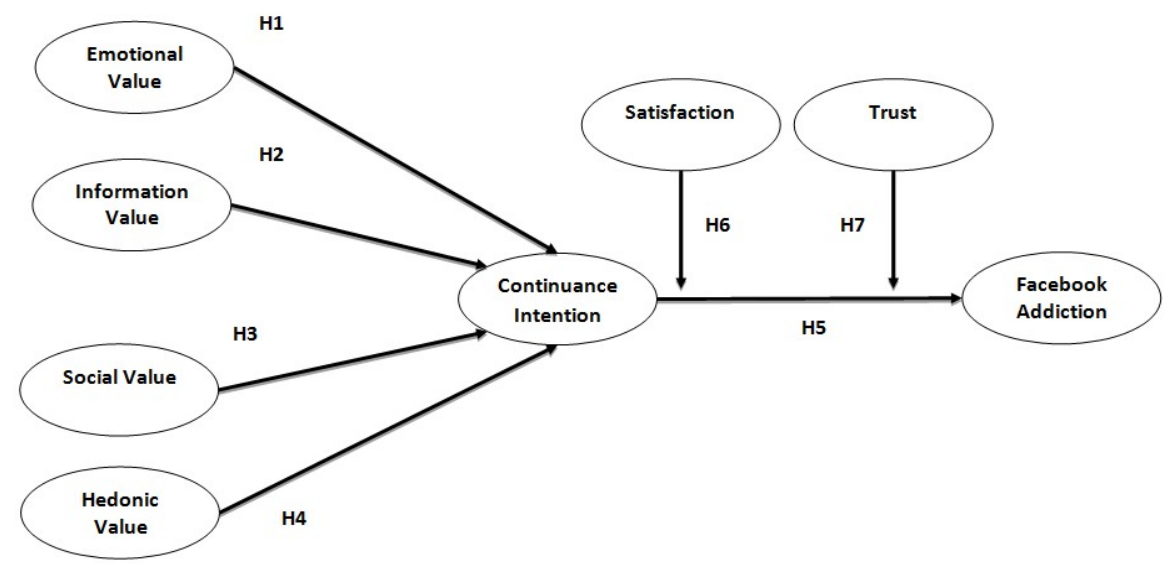

Figure 1. Research model.

\subsection{Measurement Development}

As seen in Table 2, eight variables were measured in this research (i.e., hedonic value, emotional value, informational value, social value, continuance intention, Facebook addiction, satisfaction, and trust). As shown in Appendix A, these variables were operationalised from previously validated studies where standard measures were used [7,25,31,63,73]. A 5-point Likert scale ranging from " $1=$ strongly disagree" to " $5=$ strongly agree" is used to measure the questionnaire items for the six variables. The preliminary instrument was pre-tested in ten semi-structured interviews with Facebook users and seven academic professors from the Jordan University School of Business to test its completeness, relevance, clarity, and length. This process led to numerous minor amendments to the survey questions.

Table 2. Definitions of variables.

\begin{tabular}{|c|c|c|}
\hline Constructs & Definitions & Sources \\
\hline Emotional Value (EV) & $\begin{array}{l}\text { It refers to the emotional satisfaction and comfort attained from Facebook } \\
\text { social support and communications. }\end{array}$ & {$[25,31]$} \\
\hline Information Value (IV) & $\begin{array}{l}\text { It refers to the advantages of obtaining useful information from Facebook } \\
\text { expert information providers or friends. }\end{array}$ & {$[25,31]$} \\
\hline Social Value (SV) & $\begin{array}{l}\text { It refers to the perceived usefulness of users in constructing and preserving } \\
\text { interpersonal relationships effectively, representing themselves, seeking } \\
\text { companionship, and pursuing Facebook social approval. }\end{array}$ & {$[1,25,31]$} \\
\hline Hedonic Value (HV) & $\begin{array}{l}\text { It refers to the ability of Facebook to provide innovation, elicit curiosity, } \\
\text { and/or satisfy aspirations to seek knowledge. }\end{array}$ & {$[1,25,31]$} \\
\hline Continuance Intention $(\mathrm{CI})$ & It refers to the initial decision by Facebook users to reuse the website. & {$[25,31]$} \\
\hline Facebook Addiction (FA) & $\begin{array}{l}\text { It refers to Facebook excessive use and psychological dependence that } \\
\text { obstructs other important actions and has negative impacts. }\end{array}$ & [7] \\
\hline Trust (TR) & $\begin{array}{l}\text { It refers to the tendency to believe in others and their posted articles on the } \\
\text { Facebook website. }\end{array}$ & [1] \\
\hline Satisfaction (ST) & $\begin{array}{l}\text { It refers to a user's judgments about how well that service provides a level } \\
\text { of fulfilment from Facebook. }\end{array}$ & [63] \\
\hline
\end{tabular}

\subsection{Survey Description}

A paper-based survey was used to collect data from undergraduate business students at the University of Jordan with Facebook experience. Students who were interested in participating in the study started the survey upon their consent of participation. The study was conducted between 15 December 2019 and 25 February 2020. A total number of 602 students randomly volunteered to fill out the questionnaire. We eliminated 30 data points with significant missing data and 572 were used in the analysis, which leads to a response rate of $95 \%$. 
According to the University of Jordan registration unit, the study population consisted of 4000 undergraduate students from the School of Business. The researchers conducted the current research project, and the ethical committee of the School of Business at The University of Jordan (UoJ) approved it. In addition, the researchers explained the purpose of the study to the participants and obtained informed consent from those who took part in the survey. Hence, both the research process and questionnaire were approved appropriately.

Participants were selected randomly amongst the entire student population. However, what constitutes an adequate sample size for regression analysis is uncertain among researchers. Some researchers [74] recommend that the sample size of a study that applies multiple linear regression should be 100 participants or more than five times the number of items measured. The questionnaire was made up of 32 items, so the sample size should be over 160 students. Hair et al. (2014) [75] recommended between 100 and 200, while [76] required 351 from a population of 4000. Therefore, the number of returned surveys was 572 to meet the requirement of sample size for a structural equation model and show adequate representation with the highest probability assessment. In Table 3, the respondents' characteristics of this study are summarised.

Table 3. Characteristics of the research sample $(n=572)$.

\begin{tabular}{|c|c|c|c|}
\hline Category & Category & Frequency & Percentage $\%$ \\
\hline \multirow{2}{*}{ Gender } & Male & 178 & 31.1 \\
\hline & Female & 394 & 68.9 \\
\hline \multirow{3}{*}{ Age } & $17-19$ & 97 & 17.0 \\
\hline & $20-23$ & 431 & 75.3 \\
\hline & 23 and above & 44 & 7.7 \\
\hline \multirow{5}{*}{ Academic Level (Year) } & First & 20 & 3.5 \\
\hline & Second & 165 & 28.9 \\
\hline & Third & 180 & 31.5 \\
\hline & Fourth & 169 & 29.5 \\
\hline & Fifth and above & 38 & 6.6 \\
\hline \multirow{4}{*}{$\begin{array}{l}\text { Students Time Spent on Social } \\
\text { Networking Activities Daily (Hour) }\end{array}$} & Less than 1 & 69 & 12.1 \\
\hline & $1-3$ & 238 & 41.6 \\
\hline & $4-6$ & 187 & 32.7 \\
\hline & More than 6 & 78 & 13.6 \\
\hline \multirow{4}{*}{$\begin{array}{c}\text { Number of Times Using Facebook } \\
\text { Sites (Weekly) }\end{array}$} & Less than ten times & 70 & 12.3 \\
\hline & 10-29 times & 193 & 33.7 \\
\hline & 30-50 times & 153 & 26.7 \\
\hline & More than 50 times & 156 & 27.3 \\
\hline
\end{tabular}

\subsection{Respondents' Demographic Information}

As shown in Table 3, among the 572 participants, 394 were females $(68.9 \%)$ and 178 were males (31.1\%). Many of the participants were between 20 and 23 years old (431, 75.3\%), followed by 17-19 years old (97, 17\%) and then 23 years old and above $(44,7.7 \%)$. Most of the respondents were in their second, third, and fourth years of education (514, 89.90\%), with the first and fifth year and above students $(58,10.10 \%)$. Regarding the number of hours spent on Facebook every day, most participants used Facebook between 1 and $3 \mathrm{~h}$ daily (238, $41.6 \%)$, and others used it $4-6 \mathrm{~h}$ per day $(187,32.7 \%)$ or more than $6 \mathrm{~h}(78,13.6 \%)$. As for the number of times using Facebook weekly, participants used Facebook 10-29 times (193, $33.7 \%)$, more than 50 times $(156,27.3 \%)$, followed by $30-50$ times $(153,26.7 \%)$, and less than 10 times $(70,12.3 \%)$ respectively. 


\section{Analysis Results}

\subsection{Reliability and Validity}

Exploratory factor analysis (EFA) was employed to improve the scale of this research. First, the independent variables were entered into one model and tested using maximum likelihood extraction based on eigenvalue $>1$; the $\mathrm{KMO}$ values were 0.85 , which is above the threshold of acceptability (i.e., 0.5) [77,78], and Bartlett's tests of sphericity were significant, which designated that the research data were suitable for EFA. The items were loaded into four factors, and to improve the quality of factor analysis, one item was excluded from the "information value" due to low commonalities (i.e., 0.167) [79]. The EFA was repeated for the moderators and the dependent variables. All the KMO results ranged between 0.726 and 0.808 , and Bartlett's tests of sphericity were significant. Two items from the trust scale were removed, since they were loaded separately. The results are presented in Table 4 .

Table 4. Exploratory factor analysis result.

\begin{tabular}{cccc}
\hline Latent Variable & KMO & $\begin{array}{c}\text { \% of Variance } \\
\text { Explained }\end{array}$ & $\begin{array}{c}\text { Number of } \\
\text { Indicators }\end{array}$ \\
\hline $\begin{array}{c}\text { Emotional Value } \\
\text { Social Value }\end{array}$ & & & 3 \\
Hedonic Value & 0.846 & $49.8 \%$ & 4 \\
Information Value & & & 3 \\
Continuous Intention & 0.797 & $56.06 \%$ & 3 \\
Addiction & 0.751 & $44.867 \%$ & 4 \\
Satisfaction & 0.808 & $60.706 \%$ & 4 \\
Trust & 0.726 & $51.437 \%$ & 6 \\
\hline
\end{tabular}

To confirm the validity of the measures, confirmatory factor analysis (CFA) was conducted. All the research items that were kept after the EFA were entered into a model; the standardised factor loading for the items is presented in Table 5, all items loaded above 0.55 , and one item from the satisfaction scale was removed, since the error term for that question showed high covariance value with addiction (i.e., Satisfaction 4). Finally, two items were removed from trust due to standardised factor loading less than 0.55).

According to Hoyle (2012), $\chi^{2} / \mathrm{df}$ should stay between one and three [80]. The normed fit index (NFI), increment fit index (IFI), Tucker-Lewis fit index (TLI), and comparative fit index (CFI) should be greater than 0.9. The goodness-of-fit index (GFI) should be greater than 0.9 , whereas a root means square error of approximation (RMSEA) value below 0.08 means a decent fit, while values $<0.05$ would mean a good fit. In addition to model fit indices, structural equation modelling required the evaluation of other criteria. According to Haier et al. (2011), the criteria are internal consistency reliability (i.e., composite reliability (CR); $\mathrm{CR}>0.7$ ) [81]; indicator reliability, which is assessed by evaluating standardised $>0.55$ [82]; and finally, convergent validity, which is assessed by average variance extracted (AVE), using Fornell and Larcker criteria AVE $>0.5$. Discriminant validity, according to Fornell and Larcker criteria, is achieved when the AVE of each latent construct is higher than the construct's highest squared correlation with any other latent construct [81,83]. Additionally, to confirm the reliability of the measures, Cronbach's alpha values were calculated with cut points of 0.7 [83].

Accordingly, the research model was analysed using IBM SPSS and AMOS 22. First, as can be seen in Table 6, the table presents the standardised loading of the observed items on their latent construct. All the items show standardised loading higher than 0.55 [81]. Regarding the model fit indices $\chi^{2}=743.741, \chi^{2} / \mathrm{df}=2.31<3$, GFI $=0.912, \mathrm{NFI}=0.928$, TLI $=0.915$, $\mathrm{CFI}=0.927$, and RMSAE $=0.048$. This indicates that all the fit indices meet the required standards. Figure 2 present the CFA of the research model (standardised values). 
Table 5. Validity and reliability.

\begin{tabular}{cccc}
\hline Item & Cronbach's Alpha & $\begin{array}{c}\text { Composite } \\
\text { Reliability }\end{array}$ & AVE \\
\hline Social value (SV) & 0.712 & 0.723 & $0.400^{*}$ \\
Hedonic value (HV) & 0.698 & 0.709 & $0.451^{*}$ \\
Information value (IF) & 0.766 & 0.774 & 0.534 \\
Emotional value (EV) & 0.70 & 0.710 & $0.454^{*}$ \\
Facebook addiction (FA) & 0.761 & 0.763 & $0.449^{*}$ \\
Continuous intention (CI) & 0.831 & 0.835 & 0.560 \\
Trust (TR) & 0.771 & 0.773 & 0.460 * \\
Satisfaction (ST) & 0.835 & 0.843 & 0.645 \\
\hline
\end{tabular}

${ }^{*}$ Although the AVE is less than 0.5, according to [81], AVE is a more conservative criterion than CR. Accordingly, if the CR is higher than 0.7, an AVE less than 0.5 can be accepted.

Table 6. Standardised loading, standard error, and composite reliability.

\begin{tabular}{|c|c|c|c|c|c|}
\hline \multicolumn{2}{|c|}{ Item } & \multirow{2}{*}{$\begin{array}{c}\begin{array}{c}\text { Unstandardised } \\
\text { Loading }\end{array} \\
1.000\end{array}$} & \multirow{2}{*}{$\begin{array}{c}\begin{array}{c}\text { Standardised } \\
\text { Loading }\end{array} \\
0.776\end{array}$} & \multirow[t]{2}{*}{$\begin{array}{l}\text { Standard } \\
\text { Error }\end{array}$} & \multirow[t]{2}{*}{$\begin{array}{l}\text { Composite } \\
\text { Reliability }\end{array}$} \\
\hline SV4 & A4 & & & & \\
\hline SV3 & A3 & 0.724 & 0.547 & 0.064 & 11.310 \\
\hline SV2 & A2 & 0.701 & 0.551 & 0.062 & 11.380 \\
\hline SV1 & A1 & 0.893 & 0.628 & 0.070 & 12.762 \\
\hline HV3 & A7 & 1.182 & 0.685 & 0.105 & 11.274 \\
\hline HV2 & A6 & 1.199 & 0.740 & 0.103 & 11.635 \\
\hline HV1 & A5 & 1.000 & 0.580 & & \\
\hline IV3 & A16 & 1.049 & 0.715 & 0.076 & 13.829 \\
\hline IV2 & A15 & 1.114 & 0.797 & 0.076 & 14.604 \\
\hline IV1 & A14 & 1.000 & 0.676 & & \\
\hline EV3 & A20 & 0.807 & 0.554 & 0.073 & 11.044 \\
\hline EV2 & A19 & 1.127 & 0.748 & 0.083 & 13.589 \\
\hline EV1 & A18 & 1.000 & 0.703 & & \\
\hline FA1 & A21 & 1.000 & 0.562 & & \\
\hline FA2 & A22 & 1.222 & 0.684 & 0.111 & 11.024 \\
\hline FA3 & A23 & 1.362 & 0.713 & 0.121 & 11.239 \\
\hline FA4 & A24 & 1.352 & 0.709 & 0.121 & 11.211 \\
\hline CI1 & A29 & 1.000 & 0.826 & & \\
\hline $\mathrm{CI} 2$ & A30 & 0.883 & 0.713 & 0.050 & 17.774 \\
\hline CI3 & A31 & 0.932 & 0.792 & 0.046 & 20.105 \\
\hline CI4 & A32 & 0.782 & 0.651 & 0.049 & 15.931 \\
\hline TR1 & A8 & 1.000 & 0.617 & & \\
\hline TR2 & A9 & 1.181 & 0.715 & 0.095 & 12.404 \\
\hline TR3 & A10 & 1.245 & 0.706 & 0.101 & 12.325 \\
\hline TR4 & A11 & 1.091 & 0.671 & 0.091 & 11.959 \\
\hline ST1 & A25 & 1.000 & 0.673 & & \\
\hline ST2 & A26 & 1.262 & 0.867 & 0.073 & 17.353 \\
\hline ST3 & A27 & 1.237 & 0.854 & 0.072 & 17.221 \\
\hline
\end{tabular}

The research data were collected using a self-reported method. Consequently, the common-method variance should be tested to eliminate this issue by using Harman's singlefactor test. In this test, the items of all the variables should be entered in an EFA. If no single factor emerges from the analysis and no single factor was responsible for the majority of the variance, common method bias should not be an issue [84]. Seven variables with eigenvalues higher than one were found; the percentage variances of the factors were $(26.493,8.298,6.6,5.227,4.3,4.096$, and 3.887). No single factor was responsible for more than $50 \%$ of the variance, so accordingly, common method variance was not an issue. 


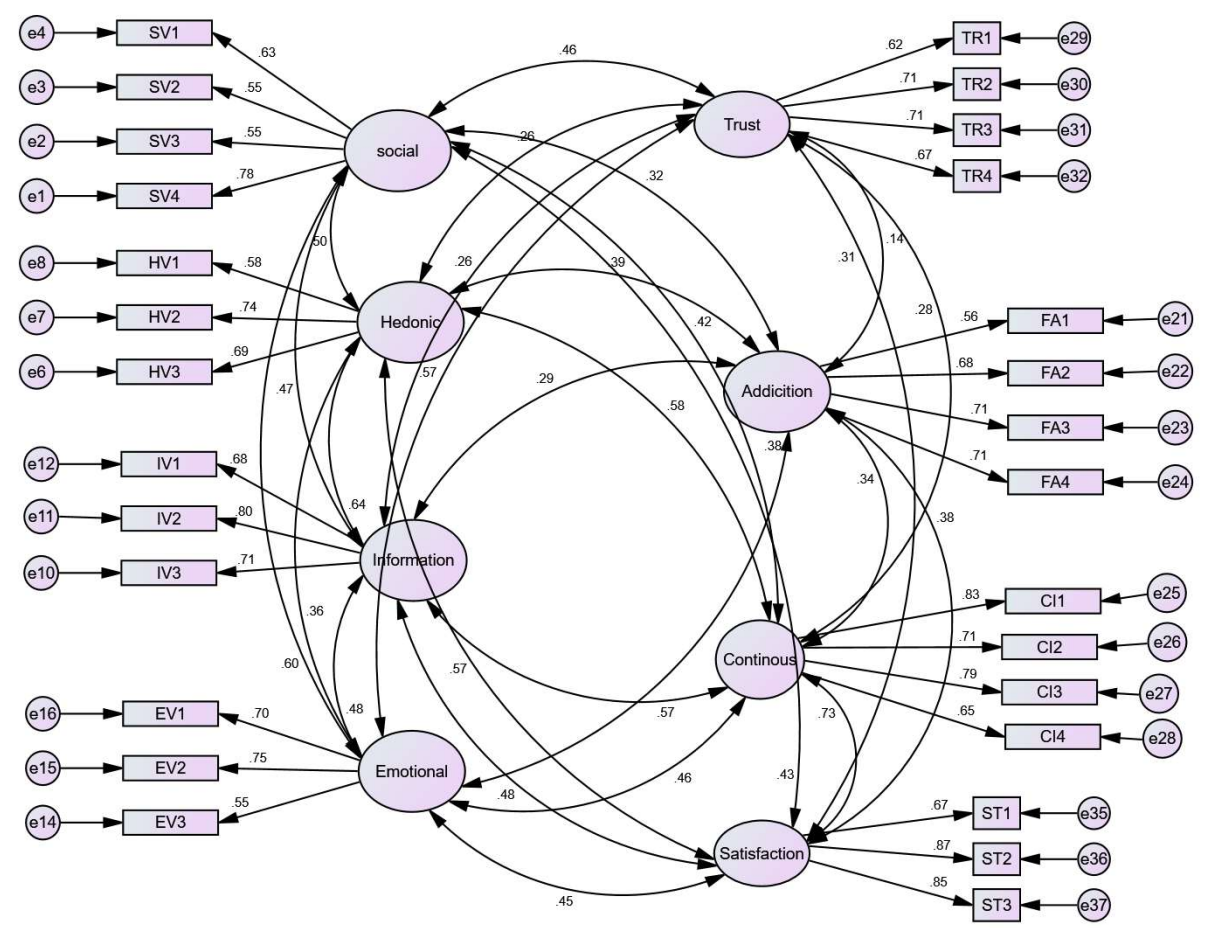

Figure 2. The CFA for the research model.

The correlation matrix was produced to confirm that there were no multicollinearity issues (e.g., no correlation higher than 0.9 [83]) and to check linear correlations among the tested variables; the results are presented in Table 7. The significance of the correlations is an indication of the existence of a linear relationship between the variables. Additionally, the means and standard deviations of the study variable were calculated, and the results are presented in Table 7. From the results, we can see that the highest mean scores were for information value, followed by hedonic value and continuous intention, while the lowest mean score was trust and emotional value. The criterion for univariate normality indicated that skewness and Kurtosis values should be between +2 and -2 to be normally distributed, and this was achieved in this sample [85].

Table 7. Descriptive statistics and correlations matrix.

\begin{tabular}{|c|c|c|c|c|c|c|c|c|}
\hline Construct & Trust & Social & Hedonic & Information & Emotional & Addiction & Continuous & Satisfaction \\
\hline Trust & 0.678 & & & & & & & \\
\hline Social & 0.461 & 0.632 & & & & & & \\
\hline Hedonic & 0.265 & 0.504 & 0.672 & & & & & \\
\hline Information & 0.262 & 0.473 & 0.636 & 0.731 & & & & \\
\hline Emotional & 0.575 & 0.599 & 0.364 & 0.48 & 0.673 & & & \\
\hline Addiction & 0.141 & 0.325 & 0.388 & 0.286 & 0.381 & 0.67 & & \\
\hline Continuous & 0.283 & 0.416 & 0.576 & 0.569 & 0.461 & 0.338 & 0.749 & \\
\hline Satisfaction & 0.31 & 0.43 & 0.573 & 0.484 & 0.453 & 0.384 & 0.727 & 0.803 \\
\hline Mean & 1.76 & 3.21 & 2.76 & 2.95 & 2.67 & 2.15 & 3.47 & 2.58 \\
\hline $\mathrm{SD}$ & 0.533 & 0.741 & 0.578 & 0.587 & 0.654 & 0.637 & 0.816 & 0.634 \\
\hline Skewness & 0.188 & -0.457 & -0.653 & -1.08 & -0.146 & -0.094 & -0.53 & -0.412 \\
\hline Kurtosis & -0.232 & 0.038 & 0.497 & 1.75 & -0.341 & -0.667 & 0.31 & 0.237 \\
\hline
\end{tabular}

The diagonal line in bold italic represents the square root of the latent construct AVE values to be compared with the latent construct correlations to assess discriminant validity. As can be seen, discriminant validity is achieved for all the constructs.

\subsection{Hypotheses Testing}

Structural equation modelling (SEM) is a technique that is used to reduce the number of observed variables into a smaller number of latent variables by examining the covariance between the variables; it can also be described as a mix between factor analysis and 
regression [83]. It is also known as path analysis for latent variables. Before running SEM, a few essential aspects should be evaluated: first, sample size, which is adequate for SEM as mentioned earlier; second, missing data, no missing data were reported in this research; third, the model fit should be examined, and as indicated earlier, the model has acceptable fit indices.

The structural model was tested to look at the relationships between the four independent constructs (social, emotional, information, and hedonic values) and the two dependent variables, continuous intention and Facebook addiction. As shown in Figure 3 and Table 8, all the relationships were positive and significant, except for the social value effect on continuous intention. Furthermore, the paths (Social value $\rightarrow$ Continuous intention $=0.005, p=0.947$; and Emotional value $\rightarrow$ Continuous intention, $=0.238, p<0.001$; Information value $\rightarrow$ Continuous intention, $=0.242, p<0.001$ and Hedonic value $\rightarrow$ Continuous intention, $=0.338, p<0.001$ ). The variance in continuous intention due to the four independent variables is moderate $40.3 \%$ [83]. Therefore, hypotheses $\mathrm{H} 1, \mathrm{H} 2$, and $\mathrm{H} 4$ were supported, while hypothesis $\mathrm{H} 3$ was not supported. Finally, the path Continuous intention $\rightarrow$ Facebook addiction $=0.369, p<0.001$, with a moderate variance of $44.9 \%$. Therefore, hypothesis $\mathrm{H} 5$ was supported.

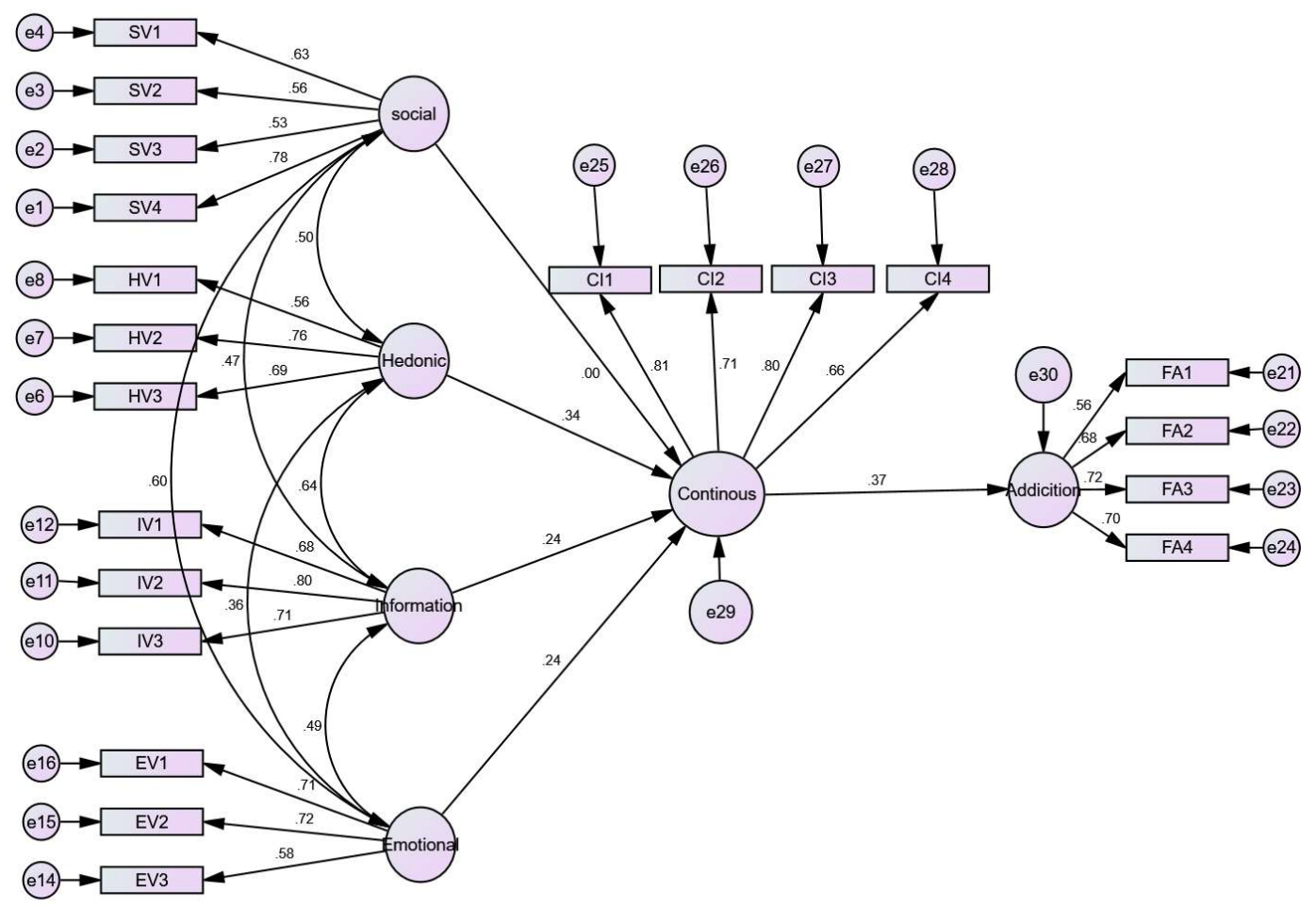

Figure 3. Path analysis for $\mathrm{H} 1$ to $\mathrm{H} 5$ (standardised values).

A Macro PROCESS model (1) was used to test the moderation effect (i.e., H6 and H7). Bootstrapping was used to test the significance of all the effects. Bootstrapping will resample 5000 times the data and produce $95 \%$ bias-corrected confidence intervals $(95 \%$ CI) of all the effects. If the confidence interval contains zero, the effects are insignificant. The variables were standardised to get the standardised effect, and the moderation model was mean-centred to avoid multicollinearity.

For H6, the moderation model was first tested for multicollinearity, as can be seen from the table tolerance values being $>0.1$ and variance inflation factor (VIF) $<4$, which indicate that there was no multicollinearity issue [85]. The model was evaluated by looking at the $\mathrm{R}^{2}$ value; as can be seen from the table, this value equals 0.216 , which mean that the moderation model explains $21.6 \%$ of the variance in the dependent variable (Facebook addiction). To assess the statistical significance of the result, the F value was 
examined $(\mathrm{F}=52.172, p=0.000<0.05)$; accordingly, the results are statistically significant. The constant represents the intercept of the regression line with the $\mathrm{x}$-axis, while the explanation of the intercept value depends on the characteristics of the dependent variable: it only has a meaning if the value zero is meaningful for the independent variable [75]. Accordingly, in this regression, the constant value does not have any explanatory value. The interaction term was examined to test the moderation effect; as can be seen from the table, the moderation effect is negative and significant, indicating a negative significant moderation effect of satisfaction on the relationship between continuous intention and addiction. Furthermore, looking into the individual effect at three levels $(-1$ SD, 0 and $+1 \mathrm{SD}$ ), it can be seen that the moderation effect was not significant for high and mean values of satisfaction. However, the significant moderation effect was only significant for the low level of satisfaction ( $-1 \mathrm{SD})$, and the effect was positive. The results are shown in Table 9.

Table 8. Result for testing H1 to H5.

\begin{tabular}{|c|c|c|c|c|c|c|c|c|}
\hline $\begin{array}{c}\text { Dependent } \\
\text { Variables }\end{array}$ & & $\begin{array}{c}\text { Independent } \\
\text { Variables }\end{array}$ & Standardised & Estimate & S.E. & CR. & $p$ & Result \\
\hline $\begin{array}{l}\text { Continuous } \\
\text { intention }\end{array}$ & $<-$ & Emotional value & 0.238 & 0.273 & 0.079 & 3.471 & $* * *$ & $\begin{array}{c}\mathrm{H} 1 \\
\text { Significant }\end{array}$ \\
\hline $\begin{array}{l}\text { Continuous } \\
\text { intention }\end{array}$ & $<-$ & Information value & 0.242 & 0.318 & 0.094 & 3.395 & $* * *$ & $\begin{array}{c}\mathrm{H} 2 \\
\text { Significant }\end{array}$ \\
\hline $\begin{array}{l}\text { Continuous } \\
\text { intention }\end{array}$ & $<-$ & Social value & 0.005 & 0.005 & 0.070 & 0.066 & 0.94 & $\begin{array}{c}\mathrm{H} 3 \\
\text { Insignificant }\end{array}$ \\
\hline $\begin{array}{l}\text { Continuous } \\
\text { intention }\end{array}$ & $<-$ & Hedonic value & 0.338 & 0.463 & 0.102 & 4.526 & $* * *$ & $\begin{array}{c}\text { H4 } \\
\text { Significant }\end{array}$ \\
\hline $\begin{array}{l}\text { Facebook } \\
\text { addiction }\end{array}$ & $<-$ & Continuous intention & 0.369 & 0.311 & 0.047 & 6.565 & $* * *$ & $\begin{array}{c}\text { H5 } \\
\text { Significant }\end{array}$ \\
\hline
\end{tabular}

SE: Standard Error, CR: Composite Reliability, ${ }^{* * *}(p<0.01)$ : 1-tailed test.

Table 9. Moderator regression analysis (testing hypothesis 6).

\begin{tabular}{|c|c|c|c|c|c|c|c|}
\hline \multirow{3}{*}{ Hypotheses } & \multirow{3}{*}{$\begin{array}{c}\text { Standardised } \\
\text { Coefficient } \\
\beta\end{array}$} & \multicolumn{4}{|c|}{ Hypothesis 6} & \multirow{2}{*}{\multicolumn{2}{|c|}{$\begin{array}{c}\text { Collinearity } \\
\text { Statistics }\end{array}$}} \\
\hline & & \multirow{2}{*}{$t(p)$} & \multirow{2}{*}{$\begin{array}{c}\text { Bootstrapped } \\
\text { SE }\end{array}$} & \multirow[t]{2}{*}{ Bootstrapped 95\% CI } & \multirow{2}{*}{ Result } & & \\
\hline & & & & & & Tolerance & VIF \\
\hline Constant & 0.0477 & $\begin{array}{c}1.1054 \\
(0.2695)\end{array}$ & 0.0435 & -0.0423 to 0.1318 & & & \\
\hline Continuance intention $(\mathrm{CI})$ & 0.0991 & $1.566(0.1179)$ & 0.0684 & -0.0329 to 0.2354 & & 0.345 & 2.902 \\
\hline Satisfaction (SA) & 0.350 & $5.568(0.000)$ & 0.0671 & 0.2157 to 0.4787 & & 0.349 & 2.863 \\
\hline$C I * S A$ & -0.0593 & $\begin{array}{l}-2.1703 \\
(0.0304)\end{array}$ & 0.0274 & -0.1110 to -0.0038 & Significant & 0.913 & 1.096 \\
\hline $\begin{array}{c}\mathrm{R} \\
\mathrm{R}^{2} \\
\mathrm{~F} \\
(p)\end{array}$ & $\begin{array}{c}0.4648 \\
0.2160 \\
52.172 \\
(0.0000) \\
\end{array}$ & & & & & & \\
\hline \multicolumn{8}{|c|}{ The individual effects at low, medium, and high levels of satisfaction. } \\
\hline Satisfaction level & Effect & $t(p)$ & SE & $95 \% \mathrm{CI}$ & Result & & \\
\hline$(-1 \mathrm{SD})$ & 0.1584 & $\begin{array}{c}2.415 \\
(0.0160)\end{array}$ & 0.0656 & 0.0296 to 0.2872 & significant & & \\
\hline 0 & 0.0991 & $\begin{array}{c}1.566 \\
(0.1179)\end{array}$ & 0.0633 & -0.0252 to 0.2234 & & & \\
\hline (+1 SD) & 0.0398 & $\begin{array}{c}0.5523 \\
(0.5809)\end{array}$ & 0.0721 & -0.1018 to 0.1815 & & & \\
\hline
\end{tabular}

For H7, the moderation model was first tested for multicollinearity, as can be seen from the table tolerance values being $>0.1$ and variance inflation factor $(\mathrm{VIF})<4$, which indicate no multicollinearity issue [82]. The model was evaluated by looking at the $\mathrm{R}^{2}$ value; as can be seen from the table, this value equals 0.1721 , which means that the moderation 
model explains $17.21 \%$ of the variance in the dependent variable (Facebook addiction). To assess the statistical significance of the result, the $\mathrm{F}$ value was examined $(\mathrm{F}=39.35$, $p=0.000<0.05$ ), but the moderation effect was not supported, since the $95 \% \mathrm{CI}$ of the interaction effect contains zero. The results are shown in Table 10.

Table 10. Moderator regression analysis (testing hypothesis 7).

\begin{tabular}{|c|c|c|c|c|c|c|c|}
\hline \multicolumn{8}{|c|}{ Hypothesis 7} \\
\hline \multirow{2}{*}{ Hypotheses } & \multirow{2}{*}{ Coefficient B } & \multirow{2}{*}{$t(p)$} & \multirow{2}{*}{$\begin{array}{c}\text { Bootstrapped } \\
\text { SE }\end{array}$} & \multirow{2}{*}{ Bootstrapped $95 \%$ CI } & \multirow{2}{*}{ Support } & \multicolumn{2}{|c|}{ Collinearity Statistics } \\
\hline & & & & & & Tolerance & VIF \\
\hline Constant & 0.0223 & $\begin{array}{c}0.5569 \\
(0.5778)\end{array}$ & 0.0392 & -0.0555 to 0.1003 & & & \\
\hline $\begin{array}{l}\text { Continuance } \\
\text { intention (CI) }\end{array}$ & 0.3775 & $\begin{array}{c}9.2212 \\
(0.0000)\end{array}$ & 0.0439 & 0.2904 to 0.4605 & & 0.870 & 1.150 \\
\hline Trust (TR) & 0.0536 & $\begin{array}{c}1.3207 \\
(0.1871)\end{array}$ & 0.0413 & -0.0260 to 0.1363 & & 0.855 & 1.130 \\
\hline$C I * T R$ & -0.0659 & $\begin{array}{l}-1.8449 \\
(0.0656)\end{array}$ & 0.0356 & -0.1316 to 0.0067 & Insignificant & 0.980 & 1.020 \\
\hline $\begin{array}{l}\mathrm{R} \\
\mathrm{R}^{2}\end{array}$ & $\begin{array}{l}0.4148 \\
0.1721\end{array}$ & & & & & & \\
\hline $\mathrm{F}(p)$ & $39.357(0.0000)$ & & & & & & \\
\hline
\end{tabular}

\section{Discussion}

Facebook does not aim to provide a solution for a particular problem or emotional relief; instead, it aims to allow people to connect for fun and pleasure. Based on a sample of 572 students who used Facebook, the informational, hedonic, and emotional values were predictors of users' continuance intention and in turn, this enhances their addiction to this social network platform. This research aims to examine comprehensively the relationship between continuance intention and addiction in the context of Facebook as a social network. The major concerns are examining the moderating effect of satisfaction and trust on the relationship between continuance intention and Facebook addiction and what the antecedents of continuance intention will be. This study found the coefficient of determination $\mathrm{R}^{2}$ in support of the study's endogenous constructs for continuance intention, as well as Facebook addiction $=0.409$ and 0.443 correspondingly, which shows that the model reports for the variation of both endogenous constructs, namely continuance intention and Facebook addiction of the proposed model. Results revealed that continuance intention has a significant positive effect on addiction. However, satisfaction applies a negative moderation effect on the relation, while trust moderator effects are not significant. This research analysis and tests confirmed that our proposed model has the authority to explain the continuance intention of Facebook users and their impact on addiction. Thus, this research establishes the important effect of perceived values on Facebook continuance intention and addiction.

In discussing the first hypothesis (H1), which proposed that emotional value positively influences continuance intention, the results showed ample support for this hypothesis. This suggests that the more the user perceives the emotional benefits of using Facebook, the higher his/her social platform continuance intention to use will be. This result is consistent with the findings of Yang et al. (2018), which linked perceived values on mobile GSM continuance intention. However, it is inconsistent with the findings of the previous research [25] that linked emotional value with WeChat continuance intention. Generally, this demonstrates that the emotional comforts provided by Facebook through certain tools, features, and applications, such as commenting, sharing, likes, and gaming features, certainly increases the intention to continue to use this platform for respondents. This also means that users will return to this platform whenever they wish to receive support, affirmation, care, or joy. The second hypothesis $(\mathrm{H} 2)$ proposed that informational value is positively related to continuance intention. The empirical support provided suggested that the user's perceived informational benefits that he/she receives from using Facebook will also increase his/her intention to continue using the social platform. This result is also in step with previous studies $[19,31]$. However, it is incongruent with the findings of Zhang 
et al. (2017) [25]. Consequently, this finding demonstrates the influence and importance of gaining informational and useful knowledge from the user's social circle on Facebook in driving continuance intention to use the platform repeatedly.

Regarding H3, which proposed that social value will predict continuance intention, the analysis results show social value had no significant on Facebook continuance intention; this is supported by the findings of [1] (Pihlström and Brush, 2008). Nowadays, there are many available online platforms with a variety of alternatives for social interactions. Thus, they may use other communication channels rather than Facebook to get an impression of other people and/or social approval and acceptance. Facebook users may have built strong and long-term relationships with other Facebook users. Consequently, social values appeared not to be an important motivation behind the continuance intention to use Facebook.

$\mathrm{H} 4$ proposed that hedonic value will also predict continuance intention, and the outcomes of this study provided support to this hypothesis and thus were also consistent with the findings of previous research studies $[1,19,25,31]$. This means that the fun and enjoyment of using Facebook is also a predictor of continuance intention.

Hypothesis $\mathrm{H} 5$ proposed that continuance intention positively affects Facebook addiction, and the results of this study supported the same. This finding was also supported by previous research looking at the link between continuance intention and behaviour $[47,55]$. This suggests that the greater a user's intention to use Facebook, the more likely it is that they will become addicted to it. This is an important contribution here, as this relationship has never been examined before. This finding demonstrates that continuous use of Facebook will eventually lead to addiction, due to the values that the users receive every time they use this platform. Thus, repeated use of Facebook will lead users to have a dependency on the social, informative, and emotional values this platform provides.

Hypothesis H6 proposed that satisfaction would have a moderator effect on the impact of continuance intention on Facebook addiction. The analysis results confirmed the negative moderation effect of satisfaction on the relationship between continuous intention and addiction. Furthermore, the moderation effect was not significant for high and mean values of satisfaction. Nevertheless, the significant moderation effect was only significant for the low level of satisfaction. The result indicates that at a low level of satisfaction, the continuance intention negatively influences the addiction. However, when satisfaction and mean values were high, the increase in continuance intention made no significant difference (i.e., small line slope). This finding was also supported by previous research looking at the link between quality dimensions and behaviour intentions [68,69], and other researchers examined it in consumer behaviour literature [70].

Hypothesis $\mathrm{H7}$ proposed that trust would have a moderator effect on the impact of continuance intention on Facebook addiction, but the results of this study do not support this; therefore, trust does not play a role in this scenario. The hypothesis test result is consistent with the findings of previous research that examined the moderating role of trust in electronic commerce [71], and other researchers examined it in the relationship between perceived values and social networks costumer's stickiness [1].

The proposed model examined the predictive impact of values on continuance intention of Facebook users, while Zhang et al. (2017) [25] examined the effect of perceived values on continuance intentions of Chinese WeChat users, and Yang et al. (2018) examined the effect of perceived values on continuance intentions of the mobile government microblogging service in Chinese consumers. The model of Zhang et al. (2017) [25] showed that hedonic value and social value affected users' continuance intention, but the effect of informational and emotional values on continuance intention was not significant. The model of Yang et al. (2018) also showed that hedonic, informational, and social values had a positive effect on the continuance intention of users, but the effect of emotional value on continuance intention was marginal. This research showed that hedonic, informational, social, and emotional values have a positive effect on Facebook users' continuance intention. The influence of perceived values on continuance intention differs from one platform to another, as well as on the users' 
perspectives. Hence, we could not generalise the findings of this study for the same or different platforms before testing it in new settings and different countries.

Finally, the proposal in this research is based on extending the associations between perceived value and continuance behaviours theory by investigating the relationship between continuance intention and the addiction gap. It investigates the moderating role of satisfaction and trust on the relationship between continuance intention and the addiction gap.

\section{Implications}

\subsection{Theoretical Implications}

This study proposed and hypothesised the informational, hedonic, and emotional values to explain continuance intention and how it, in turn, influenced Facebook addiction among university students and reveals several theoretical implications. Several studies have focused on a single type of perceived value as a predictor of Facebook continuance intention, such as informational value [86-88] or enjoyment value [89], and they ignore the diversified values, including hedonic, emotional, and social values. The findings of this research show that a constricted focus on one type of perceived value would not capture the continuance intention of Facebook users. In contrast to many previous studies that focused on technology-related factors to explain Facebook usage behaviour $[3,90,91]$, the present study focused on the related factors that explain continuance intention behaviour by considering the hedonic, emotional, informational, and social values of Facebook users. Our results show that perceived values should be considered to explain the continuance intention of using Facebook.

As shown in Table 1, although many previous studies have explored the continuance intention of using Facebook, rarely have these studies examined how perceived values may influence users' continuance intention and further influence Facebook user addiction behaviour $[1,25,40,41]$. The present study found three types (informational, hedonic, and emotional values) of perceived values in Facebook's effect on users' continuance intention that, in turn, affects their Facebook addiction. However, these findings have important implications for Facebook and other social-network-related research, since the direct influence of perceived values is not adequate to give a full image of Facebook users' continuance intention. Furthermore, continuance intention is not the only factor that provides a rational explanation regarding the full image of Facebook addiction.

Detecting satisfaction as the moderating effect on the relationship between continuance intention and addiction becomes evident in the theoretical relevance. Thus, the results of this study will contribute to the further development of social network users satisfaction concept. Accordingly, future research can investigate the relationship between the mediating role of satisfaction on the relationship between continuance intention and social networks addiction. Finally, although the moderating role of trust in the relationship between continuance intention and addiction was not supported in this study, trust is still a necessary condition for social network users. For future research, an interesting area would be to examine the mediating role of trust on the relationship between continuance intention and social network addiction.

\subsection{Practical Implications}

This study has several practical implications. Due to the increased competition between SNS providers, continuance intention of using Facebook is vital to Facebook managers. This study provides several useful insights for social media managers and developers as well as users. This study proposes that perceived values will predict continuance intention to use Facebook. The findings confirm that informational, hedonic, and emotional values show positive impacts. Facebook's perceived values determine end users' attitudes towards continuance intention; hence, Facebook managers must focus on those values to encourage users to increase their use of this platform. Based on the results of our study, Facebook managers can enhance users' continuance intention by improving hedonic, emotional, informational, and social values. Enhancing these values is crucial for Facebook and other SNS providers. 
Facebook users play a prominent role in the impact of these values on others, and Facebook managers must consider increasing the users' role in supporting these values. Indeed, our results provide additional empirical support from a new context (Facebook users in Jordan) and show that the perceived value (i.e., benefits) of using Facebook will positively influence consumers' intention to continue using the platform. In the meantime, the current perceived values do not encompass all the factors that have a significant impact on users' continuance intention. Consequently, Facebook managers and developers must consider investigating and determining all other alternative factors.

Facebook addiction interferes with different necessary activities and yields negative results. Even if some end users perceive certain values from using Facebook, many are dissatisfied with the extensive use of the platform. On the other hand, others try unsuccessfully to reduce the time they spend on it. Thus, Facebook developers must innovatively project the website to help end users receive enhanced results of suggested friends, pages, topics, and adverts, based on users' criteria, and search and browsing history, which could help users justify to themselves and others the importance of spending time on Facebook. Facebook managers should focus their efforts on enhancing the quality of information that is displayed to the users so that they can spend their time on the website without it interfering with other important activities. Facebook users' must spend their time on the website cautiously, as the continuance intention could lead to an addiction that could have negative consequences on their life, time management and other important activities. Finally, the findings of this research are extremely relevant to Facebook users, managers, and policymakers concerning treatment and intervention for Facebook addiction among university students, which contributes to the literature. It is hoped that further research will follow to shed more light on their importance.

\section{Research Limitations and Future Research}

The nature of the data collection limits our capacity to conclude with more confidence the causal relations between the different variables examined in this study. In addition, using questionnaires as a data collection method may have created a common method variance/bias. To improve the ability to conclude causal relations and reduce common method bias, future research could employ different data collection methods (i.e., qualitative) and longitudinal research designs to possibly add more insight to this research. Another limitation related to the sample was the limitation to undergraduate students from a single university, which limits the generalisability to other contexts. Thus, valuable insights regarding the antecedents and outcomes of Facebook continuance intention and addiction systems in different national cultures can be provided by testing this model in new settings and countries. Future research replicating this study could collect data from other age categories, other Jordanian universities in different geographical regions, as well as from other contexts (e.g., individuals working in organisations) to develop more generalisable results.

Moreover, it can be very useful to examine the proposed model based on data collected from other SNS users such as Twitter, YouTube, Instagram, and LinkedIn. SNS management and Facebook managers should give significance to this research to guarantee the users' continuance intention without feeling that they are spending their time on invaluable content and, consequently, discontinue using these sites. The findings of this research are of utmost significance to the literature on this topic and it is hoped to be followed by further crucial research to shed more light on their importance.

\section{Conclusions}

Facebook is one of the largest Web 2.0 communities that has users from different countries with varying cultures, characteristics, and behaviours. This research aims to examine comprehensively the relationship between continuance intention and addiction in the context of Facebook as a social network. The major concerns are the moderating effect of satisfaction and trust on the relationship between continuance intention and Facebook addiction, and what the antecedents of continuance intention will be. The current study examines the factors 
that affect continuance intentions and their effect on Facebook users' addiction. We use satisfaction and trust to examine their mediating role between the relationship of continuance intention and addiction. To accomplish this aim, the study uses the constructs of perceived values, aiming to increase the predictive nature of the results and clarifying the continuance intention role and its effect on users' addiction. The perceived value is presented by four constructs (informational, social, hedonic, and emotional values). Interestingly, the results show that informational value, hedonic value, and emotional value were all found to have a significant effect on continuance intention, while social value has no significant impact. In addition, the results also show that continuance intention has a positive impact on users' addiction. In addition, the results of this study confirm the moderating role of satisfaction on the impact of continuance intention on Facebook addiction, while the moderating role of trust is not supported. This study is the first such study to examine the relationship of continuance intention on addiction and the moderating effects of satisfaction and trust on the relationship.

Furthermore, we compared the analysis results of the proposed model in the study with other previous studies, such as by [25,31,72]. Zhang et al. (2017) examined the impact of perceived values on continuance intentions of the WeChat social network, and Yang et al. (2018) studied the effect of perceived values on continuance intentions of Chinese mobile government microblogging service users. The results analyses of these three studies confirm the positive influence of social and hedonic values on users' continuance intention. The results of the proposed model showed that social and hedonic values have a positive effect on users' continuance intention, although the study conducted by Zhang et al. (2017) showed that the effect of informational and emotional values on continuance intention was not significant. The analysis results of the study conducted by Yang et al. (2018) showed that the effect of emotional value on continuance intention was not significant. Another study examined the moderating effects of satisfaction and trust on behavioural intention and behaviour [72]. The analysis of the results confirmed the moderating role of satisfaction and trust and enhance purchase behaviour. Analysis of the results of this research showed that informational, emotional, and hedonic values have a positive effect on Facebook users' continuance intention. Based on these results, we understand that the effect of perceived values on continuance intention is different from one platform to another as well as the users' perspectives. Thus, we could not generalise the findings of this study for the same or different platforms before testing it in new settings and countries.

In conclusion, this research endeavoured to explore important factors that influence the continuous use of Facebook and the impact of continuance intention on the addiction gap amongst a sample of youths and found that this is mostly driven by Facebook's different advantages. The study also investigates the moderating role of satisfaction and trust on the relationship between continuance intention and the addiction gap. It is the first such study to examine the relationship of continuance intention on addiction and the moderating effects of satisfaction and trust on the relationship. The results confirm the moderating role of satisfaction on the impact of continuance intention on Facebook addiction, but the moderating role of trust is not supported. Our findings indicate that when satisfaction is weak, the continuous intention will exert a more significant effect on addiction; however, when satisfaction is intense, the effect of continuous intention becomes less significant. Thus, satisfaction will have a moderating effect on this relationship between continuance intention and addiction. The result also confirms that a significant effect of continuance intention on Facebook addiction and the model achieved an acceptable fit and confirmed the effect of emotional, informational, and hedonic values on continuance intention using Facebook.

Author Contributions: Conceptualisation, M.M.; Data curation, M.M. and R.M.; Formal analysis, M.J.; Investigation, M.M. and A.O.; Methodology, M.M., Z.O. and R.M.; Project administration, M.M.; Resources, M.M. and A.O.; Software, M.M. and M.J.; Supervision, M.M., M.H.S. and R.M.; Validation, R.M.; Visualisation, M.M. and M.J.; Writing—original draft, M.M., Z.O., A.O. and M.J.; Writing-review and editing, M.M., Z.O., M.H.S. and R.M. All authors have read and agreed to the published version of the manuscript. 
Funding: This research received no external funding.

Institutional Review Board Statement: Not applicable.

Informed Consent Statement: Not applicable.

Data Availability Statement: The data presented in this study are available on request from the corresponding author.

Conflicts of Interest: The authors declare no conflict of interest.

\section{Appendix A}

Table A1. Questionnaire items.

\begin{tabular}{|c|c|c|}
\hline Construct & $\begin{array}{c}\text { Item } \\
\#\end{array}$ & Measure \\
\hline Emotional Value $[25,31]$ & $\begin{array}{l}\text { EV1 } \\
\text { EV2 } \\
\text { EV3 }\end{array}$ & $\begin{array}{l}\text { I receive adequate emotional concern from people using Facebook. } \\
\text { I feel relieved by getting sympathy from online people using Facebook. } \\
\text { I have been encouraged by friends on Facebook. }\end{array}$ \\
\hline Information Value $[25,31]$ & $\begin{array}{l}\text { IV1 } \\
\text { IV2 } \\
\text { IV3 } \\
\text { IV4 }\end{array}$ & $\begin{array}{l}\text { I accumulate numerous knowledge through shared information from Facebook users. } \\
\text { I acquire a variety of information from online people using Facebook. } \\
\text { I obtain lots of useful information from online people using Facebook. } \\
\text { Over the last month, I consulted online people using Facebook for practical issues and matters. }\end{array}$ \\
\hline Social Value $[25,31]$ & $\begin{array}{l}\text { SV1 } \\
\text { SV2 } \\
\text { SV3 } \\
\text { SV4 }\end{array}$ & $\begin{array}{l}\text { Facebook use helps me feel acceptable. } \\
\text { Facebook use improves the way I am perceived. } \\
\text { The fact that I use Facebook makes a good impression on other people. } \\
\text { Facebook use gives me social approval. }\end{array}$ \\
\hline Hedonic Value $[25,31]$ & $\begin{array}{l}\text { HV1 } \\
\text { HV2 } \\
\text { HV3 }\end{array}$ & $\begin{array}{c}\text { Compared to other things I could have done, the time spent online at the Facebook site was truly enjoyable. } \\
\text { I enjoyed being immersed in exciting new information on Facebook sites. } \\
\text { During the navigating Facebook processes, I felt the excitement of the hunt. }\end{array}$ \\
\hline $\begin{array}{c}\text { Continuance Intention } \\
\qquad[25,31]\end{array}$ & $\begin{array}{l}\text { CI1 } \\
\text { CI2 } \\
\text { CI3 } \\
\text { CI4 }\end{array}$ & $\begin{array}{l}\text { If could, I will continue using Facebook. } \\
\text { I will recommend my friends and family members to use Facebook. } \\
\text { I will continue using Facebook in the future. } \\
\text { My intentions are to continue using Facebook service rather than any alternative. }\end{array}$ \\
\hline Facebook Addiction [7] & $\begin{array}{l}\text { FA1 } \\
\text { FA2 } \\
\text { FA3 } \\
\text { FA4 }\end{array}$ & $\begin{array}{l}\text { Using my Facebook site sometimes interfered with other activities. } \\
\text { I have made unsuccessful attempts to reduce the time I interact with my Facebook site. } \\
\text { Arguments have sometimes arisen at home because of the time I spend on my Facebook site. } \\
\text { I think that I am addicted to the Facebook site. }\end{array}$ \\
\hline $\begin{array}{c}\text { Satisfaction } \\
{[60,70]}\end{array}$ & $\begin{array}{l}\text { SA1 } \\
\text { SA2 } \\
\text { SA3 } \\
\text { SA4 }\end{array}$ & $\begin{array}{l}\text { I was very content with Facebook. } \\
\text { I was very pleased with Facebook. } \\
\text { I felt delighted with Facebook. } \\
\text { Overall, I was satisfied with Facebook. }\end{array}$ \\
\hline $\begin{array}{l}\text { Trust } \\
{[1,70]}\end{array}$ & $\begin{array}{l}\text { TR1 } \\
\text { TR2 } \\
\text { TR3 } \\
\text { TR4 } \\
\text { TR5 } \\
\text { TR6 }\end{array}$ & $\begin{array}{l}\text { People on Facebook are trustworthy. } \\
\text { I trust Facebook information to be true. } \\
\text { I usually trust Facebook unless it gives me a reason not to trust it. } \\
\text { Overall, Facebook users are trustworthy. } \\
\text { Facebook respects and would not abuse my private information and browsing log history. } \\
\text { The security guard and mechanism of Facebook are trustworthy. }\end{array}$ \\
\hline
\end{tabular}

\section{References}

1. Yang, H.-L.; Lin, C.-L. Why do people stick to Facebook web site? A value theory-based view. Inf. Technol. People 2014, 27, 21-37. [CrossRef]

2. Harrigan, P.; Miles, M.P.; Fang, Y.; Roy, S.K. The role of social media in the engagement and information processes of social CRM. Int. J. Inf. Manage. 2020, 54, 102151. [CrossRef]

3. Ainin, S.; Naqshbandi, M.M.M.; Moghavvemi, S.; Jaafar, N.I.I. Facebook usage, socialization and academic performance. Comput. Educ. 2015, 83, 64-73. [CrossRef]

4. Kanat-maymon, Y.; Almog, L.; Cohen, R.; Amichai-hamburger, Y. Computers in Human Behavior Contingent self-worth and Facebook addiction. Comput. Hum. Behav. 2018, 88, 227-235. [CrossRef]

5. Facebook Inc. Facebook Reports First Quarter 2021 Results. 2021. Available online: https://investor.fb.com/investor-news/ press-release-details/2021/Facebook-Reports-First-Quarter-2021-Results / default.aspx (accessed on 17 July 2021).

6. Vishwanath, A.H. Facebook use and its impact on getting deceived on social media. J. Comput. Commun. 2015, 20, 83-98. [CrossRef] 
7. Moqbel, M.; Kock, N. Unveiling the dark side of social networking sites: Personal and work-related consequences of social networking site addiction. Inf. Manag. 2018, 55, 109-119. [CrossRef]

8. Charlton, J.P.; Danforth, I.D. Validating the distinction between computer addiction and engagement: Online game playing and personality. Behav. Inf. Technol. 2010, 29, 601-613. [CrossRef]

9. Coopersmith, S. Self-Esteem Inventories; Consulting Psychologist Press: Palo Alto, CA, USA, 1981.

10. Pianta, R.C. Professional Manual; Psychological Assessment Resources: Odessa, TX, USA, 2017.

11. Karaiskos, D.; Tzavellas, E.; Balta, G.; Paparrigopoulos, T. Social network addiction: A new clinical disorder? Eur. Psychiatry 2010, 25, 855. [CrossRef]

12. Chen, L.; Nath, R.; Tang, Z. Understanding the determinants of digital distraction: An automatic thinking behavior perspective. Comput. Hum. Behav. 2020, 104, 106195. [CrossRef]

13. Yang, H.-L.; Lai, C.-Y. Effects of Perceived Values on Continuance Usage of Facebook. In Advanced Research on Electronic Commerce, Web Application, and Communication; Springer: Berlin/Heidelberg, Germany, 2011; pp. 254-260.

14. Van Schaik, P.; Jansen, J.; Onibokun, J.; Camp, J.; Kusev, P. Security and privacy in online social networking: Risk perceptions and precautionary behaviour. Comput. Hum. Behav. 2018, 78, 283-297. [CrossRef]

15. Lakshminarasimha, A.; Vijayan, A. Value Chain Analysis: Social Networking Communities. J. Mark. 2008, VII, $34-42$.

16. Park, J.H. The effects of personalization on user continuance in social networking sites. Inf. Process. Manag. 2014, 50, 462-475. [CrossRef]

17. Shin, D.H.; Shin, Y.J. Why do people play social network games? Comput. Hum. Behav. 2011, 27, 852-861. [CrossRef]

18. Cao, H.; Jiang, J.; Oh, L.; Bin Li, H.; Liao, X.; Chen, Z. A Maslow's hierarchy of needs analysis of social networking services continuance. J. Serv. Manag. 2013, 24, 170-190. [CrossRef]

19. Kuan-Yu, L.; Hsi-Peng, L. Why people use social networking sites: An empirical study integrating network externalities and motivation theory. Comput. Hum. Behav. 2011, 27, 1152-1161.

20. Lo, J. Exploring the buffer effect of receiving social support on lonely and emotionally unstable social networking users. Comput. Hum. Behav. 2019, 90, 103-116. [CrossRef]

21. Grabner-Kräuter, S.; Bitter, S. Trust in online social networks: A multifaceted perspective. Forum Soc. Econ. 2014, 44, 48-68. [CrossRef]

22. Fang, L.; Liu, Q. Mobile SNS addiction and user continuance: An empirical investigation of wechat. Teh. Vjesn. 2019, 26, 1104-1111.

23. Bölen, M.C. Exploring the determinants of users' continuance intention in smartwatches. Technol. Soc. 2020, 60, 101209. [CrossRef]

24. Wan, C. Gratifications \& Loneliness as Predictors of Campus-Sns. Master's Thesis, The Chinese University of Hong Kong, Hong Kong, 2009.

25. Zhang, C.B.; Li, Y.N.; Wu, B.; Li, D.J. How WeChat can retain users: Roles of network externalities, social interaction ties, and perceived values in building continuance intention. Comput. Hum. Behav. 2017, 69, 284-293. [CrossRef]

26. Xu, H.; Tan, B. Why do I Keep Checking Facebook: Effects of Message Characteristic on the Formation of Social Network Services Addiction. In Proceedings of the International Conference on Information Systems, ICIS 2012, Orlando, FL, USA, 16-19 December 2012; pp. 1-12.

27. Lee, S.; Kim, B.G.; Lee, S. The impact of qualities of social network service on the continuance usage intention. Manag. Decis. 2017, 55, 701-729. [CrossRef]

28. Chiang, H.S. Continuous usage of social networking sites: The effect of innovation and gratification attributes. Online Inf. Rev. 2013, 37, 851-871. [CrossRef]

29. Chun, J.W.; Lee, M.J. Increasing individuals' involvement and WOM intention on Social Networking Sites: Content matters! Comput. Hum. Behav. 2016, 60, 223-232. [CrossRef]

30. Hong, J.C.; Lin, P.H.; Hsieh, P.C. The effect of consumer innovativeness on perceived value and continuance intention to use smartwatch. Comput. Hum. Behav. 2017, 67, 264-272. [CrossRef]

31. Yang, S.; Jiang, H.; Yao, J.; Chen, Y.; Wei, J. Perceived values on mobile GMS continuance: A perspective from perceived integration and interactivity. Comput. Hum. Behav. 2018, 89, 16-26. [CrossRef]

32. De Cock, R.; Vangeel, J.; Klein, A.; Minotte, P.; Rosas, O.; Meerkerk, G.-J. Compulsive Use of Social Networking Sites in Belgium: Prevalence, Profile, and the Role of Attitude Toward Work and School. Cyberpsychol. Behav. Soc. Netw. 2014, 17, $166-171$. [CrossRef] [PubMed]

33. Echeburua, E.; de Corral, P. Addictions to new technologies and to online social networking in young people: A new challenge. Adicciones 2010, 22, 91-96.

34. Wang, Y.; Mark, G. The context of college students' facebook use and academic performance. In Proceedings of the $2018 \mathrm{CHI}$ Conference on Human Factors in Computing Systems, Montreal, QC, Canada, 21-26 April 2018; pp. 1-11. Available online: http: / / dl.acm.org/ citation.cfm?doid=3173574.3173992 (accessed on 17 July 2021).

35. Kimberly, S. Young Internet Addiction: The Emergence of a New Clinical Disorder. CyberPsychology Behav. 1996, 1, $237-244$.

36. Sigerson, L.; Li, A.Y.L.; Cheung, M.W.L.; Cheng, C. Examining common information technology addictions and their relationships with non-technology-related addictions. Comput. Hum. Behav. 2017, 75, 520-526. [CrossRef]

37. Lemmens, J.S.; Valkenburg, P.M.; Peter, J. Psychosocial causes and consequences of pathological gaming. Comput. Hum. Behav. 2011, 27, 144-152. [CrossRef] 
38. Anderson, M. Technology Device Ownership. PewInternet. 2015. Available online: www.pewinternet.org/2015/10/29 /technology-device-ownership-2015/ (accessed on 17 July 2021).

39. Statista. Social Media Usage. Secretintelligenceservice.Org. 2019. Available online: www.secretintelligenceservice.org/wpcontent/uploads/2016/02/PI_2015-10-08_Social-Networking-Usage-2005-2015_FINAL.pdf (accessed on 17 July 2021).

40. Marengo, D.; Poletti, I.; Settanni, M. The interplay between neuroticism, extraversion, and social media addiction in young adult Facebook users: Testing the mediating role of online activity using objective data. Addict. Behav. 2020, 102, 106150. [CrossRef]

41. Wang, C.; Teo, T.S.H.; Liu, L. Perceived value and continuance intention in mobile government service in China. Telemat. Inform. 2020, 48, 101348. [CrossRef]

42. Zeithaml, V.A. Consumer Perceptions of Price, Quality, and Value: A Means-End Model and Synthesis of Evidence. J. Mark. 1988, 52, 2-22. [CrossRef]

43. Oliver, R.L.; Mano, H. Assessing the Dimensionality and Structure of the Consumption Experience: Evaluation, Feeling, and Satisfaction. J. Consum. Res. 1993, 20, 451-466.

44. Park, M.; Park, J. Exploring the influences of perceived interactivity on consumers' e-shopping effectiveness. J. Cust. Behav. 2009, 8, 361-379. [CrossRef]

45. Zhou, T.; Lu, Y. Examining mobile instant messaging user loyalty from the perspectives of network externalities and flow experience. Comput. Hum. Behav. 2011, 27, 883-889. [CrossRef]

46. Sheth, J.N.; Newman, B.I.; Gross, B.L. Why we buy what we buy: A theory of consumption values. J. Bus. Res. 1991, 22, 159-170. [CrossRef]

47. Al-Debei, M.M.; Al-Lozi, E.; Papazafeiropoulou, A. Why people keep coming back to Facebook: Explaining and predicting continuance participation from an extended theory of planned behaviour perspective. Decis. Support Syst. 2013, 55, 43-54. [CrossRef]

48. Raacke, J.; Bonds-Raacke, J. MySpace and Facebook: Applying the Uses and Gratifications Theory to Exploring Friend-Networking Sites. CyberPsychology Behav. 2008, 11, 169-174. [CrossRef] [PubMed]

49. Balakrishnan, V.; Azra, S. Malaysian Facebookers: Motives and addictive behaviours unraveled. Comput. Hum. Behav. 2013, 29, 1342-1349. [CrossRef]

50. Kupfer, A.; Ableitner, L.; Schöb, S.; Tiefenbeck, V. Technology Adoption vs. Continuous Usage Intention: Do Decision Criteria Change when Using a Technology? In Proceedings of the Americas Conference on Information Systems (AMCIS 2016), San Diego, CA, USA, 11-14 August 2016.

51. Leong, L.Y.; Hew, T.S.; Ooi, K.B.; Lee, V.H.; Hew, J.J. A hybrid SEM-neural network analysis of social media addiction. Expert Syst. Appl. 2019, 133, 296-316. [CrossRef]

52. Zong, W.; Yang, J.; Bao, Z. Social network fatigue affecting continuance intention of social networking services: The case of WeChat users in China's universities. Data Technol. Appl. 2019, 53, 123-139. [CrossRef]

53. Yang, X. Social influence or personal attitudes? Understanding users' social network sites continuance intention. Kybernetes 2019, 48, 424-437. [CrossRef]

54. Pelling, E.L.; White, K.M. The theory of planned behavior applied to young people's use of social networking Web sites. Cyberpsychol. Behav. 2009, 12, 755-759. Available online: http://www.ncbi.nlm.nih.gov/pubmed/19788377 (accessed on 17 July 2021). [CrossRef] [PubMed]

55. Turel, O.; Serenko, A.; Bontis, N. User acceptance of hedonic digital artifacts: A theory of consumption values perspective. Inf. Manag. 2010, 47, 53-59. [CrossRef]

56. Obeidat, Z.M.I.; Xiao, S.H.; Iyer, G.R.; Nicholson, M. Consumer revenge using the internet and social media: An examination of the role of service failure types and cognitive appraisal processes. Psychol. Mark. 2017, 34, 496-515. [CrossRef]

57. Ronis, D.L.; Yates, J.F.; Kirscht, J.P. Attitudes, Decisions, and Habits as Determinants of Repeated Behavior; Lawrence Erlbaum: Hillsdale, NJ, USA, 1989; pp. 213-239. Available online: https: / / books.google.com/books?hl=es\&lr=\&id=fiOvSm50Z7kC\&pgis=1 (accessed on 17 July 2021).

58. Miyazaki, A.D.; Fernandez, A. Consumer perceptions of privacy and security risks for online shopping. J. Consum. Aff. 2001, 35, 27-44. [CrossRef]

59. Maqableh, M.; Obeidat, A.; Obeidat, Z. Exploring the determinants of Internet continuance intention and the negative impact of Internet addiction on students' academic performance. Int. J. Data Netw. Sci. 2021, 5, 183-196. [CrossRef]

60. Błachnio, A.; Przepiorka, A.; Benvenuti, M.; Mazzoni, E.; Seidman, G. Relations between facebook intrusion, Internet addiction, life satisfaction, and self-esteem: A study in Italy and the USA. Int. J. Ment. Health Addict. 2019, 17, 793-805. [CrossRef]

61. Yang, S.; Liu, Y.; Wei, J. Social capital on mobile SNS addiction: A perspective from online and offline channel integrations. Internet Res. 2016, 26, 982-1000. [CrossRef]

62. Nepomuceno, M.V.; Laroche, M.; Richard, M.O. How to reduce perceived risk when buying online: The interactions between intangibility, product knowledge, brand familiarity, privacy and security concerns. J. Retail. Consum. Serv. 2014, 21, 619-629. [CrossRef]

63. Oliver, R.L. Satisfaction: A behavioral Perspective on the Consumer, 2nd ed.; Routledge: New York, NY, USA, 2014.

64. Kim, K.H.; Kim, K.J.; Lee, D.H.; Kim, M.G. Identification of critical quality dimensions for continuance intention in mHealth services: Case study of onecare service. Int. J. Inf. Manage. 2019, 46, 187-197. [CrossRef]

65. Kalinić, Z.; Marinković, V.; Djordjevic, A.; Liebana-Cabanillas, F. What drives customer satisfaction and word of mouth in mobile commerce services? A UTAUT2-based analytical approach. J. Enterp. Inf. Manag. 2019, 33, 71-94. [CrossRef] 
66. Gong, X.; Liu, Z.; Zheng, X.; Wu, T. Why are experienced users of WeChat likely to continue using the app? Asia Pac. J. Mark. Logist. 2018, 30, 1013-1039. [CrossRef]

67. Al-Ansi, A.; Olya, H.G.T.; Han, H. Effect of general risk on trust, satisfaction, and recommendation intention for halal food. Int. J. Hosp. Manag. 2019, 83, 210-219. [CrossRef]

68. Li, S.J.; Huang, Y.Y.; Yang, M.M. How satisfaction modifies the strength of the influence of perceived service quality on behavioral intentions. Leadersh. Health Serv. 2011, 24, 91-105. [CrossRef]

69. Zopiatis, A.; Theocharous, A.L.; Constanti, P.; Tjiapouras, L. Quality, Satisfaction and Customers' Future Intention: The Case of Hotels' Fitness Centers in Cyprus. J. Qual. Assur. Hosp. Tour. 2017, 18, 1-24. [CrossRef]

70. Fong, L.H.N.; He, H.; Chao, M.M.; Leandro, G.; King, D. Cultural essentialism and tailored hotel service for Chinese: The moderating role of satisfaction. Int. J. Contemp. Hosp. Manag. 2019, 31, 3610-3626. [CrossRef]

71. Alsaad, A.; Mohamad, R.; Ismail, N.A. The moderating role of trust in business to business electronic commerce (B2B EC) adoption. Comput. Hum. Behav. 2017, 68, 157-169. [CrossRef]

72. Sultan, P.; Tarafder, T.; Pearson, D.; Henryks, J. Intention-behaviour gap and perceived behavioural control-behaviour gap in theory of planned behaviour: Moderating roles of communication, satisfaction and trust in organic food consumption. Food Qual. Prefer. 2020, 81, 103838. [CrossRef]

73. Susanto, A.; Chang, Y.; Ha, Y. Determinants of continuance intention to use the smartphone banking services: An extension to the expectation-confirmation model. Ind. Manag. Data Syst. 2016, 116, 508-525. [CrossRef]

74. O'Rourke, N.; Hatcher, L. A Step-by-Step Approach to Using SAS for Factor Analysis and Structural Equation Modeling; SAS Institute Inc.: Cary, NC, USA, 2013.

75. Hair, J.; Black, W.; Babin, B.; Anderson, R. Multivariate Data Analysis. 2014. Available online: http://hym-2017.corpuscodea.es / pdf/ (accessed on 17 July 2021).

76. Hair, J.F., Jr.; Black, W.C.; Babin, B.J.; Anderson, R.E. Multivariate Data Analysis; Pearson: London, UK, 2014.

77. Krejcie, R.V.; Morgan, D.W. Determining sample size for research activities. Educ. Psychol. Meas. 1970, 30, 607-610. [CrossRef]

78. Ford, J.K.; MacCallum, R.C.; Tait, M. The application of exploratory factor analysis in applied psychology: A critical review and analysis. Pers. Psychol. 1986, 39, 291-314. [CrossRef]

79. Kaiser, H.F. An index of factorial simplicity. Psychometrika 1974, 39, 31-36. [CrossRef]

80. Hogarty, K.Y.; Hines, C.V.; Kromrey, J.D.; Perron, J.M.; Mumford, A.K.R. The quality of factor solutions in exploratory factor analysis: The influence of sample size, communality, and overdetermination. Educ. Psychol. Meas. 2005, 65, 202-226. [CrossRef]

81. Hoyle, R.H. Handbook of Structural Equation Modeling, 1st ed.; Guilford: New York, NY, USA, 2012.

82. Larcker, D.F.; Fornell, C.; Larcker, D.F. Evaluating structural equation models with unobservable variables and measurement error. J. Mark. Res. 1981, 18, 456-464.

83. Harrington, D. Confirmatory Factor Analysis; Oxford University Press: Oxford, UK, 2009. Available online: https: // oxford.universitypressscholarship.com/view/10.1093/acprof:oso/9780195339888.001.0001/acprof-9780195339888 (accessed on 17 July 2021).

84. Hair, J.; Ringle, C.; Sarstedt, M. PLS-SEM: Indeed a silver bullet. J. Mark. Theory Pract. 2011, 19, 139-151. [CrossRef]

85. Podsakoff, P.M.; Organ, D.W. Self-Reports in Organizational Research: Problems and Prospects. J. Manag. 1986, 12, 531-544. [CrossRef]

86. Garson, G.D. Testing Statistical Assumptions: Blue Book Series. 2012. Available online: www.researchgate.net/profile/Jurandy_ Penitente-Filho/post/What_is_the_best_statistical_method_to_correlate_immunohistochemestry_and_rt-pcr/attachment/59 d61d9879197b807797853c/AS:271755204071424@1441802897825/download/assumptions.pdf (accessed on 17 July 2021).

87. Schreiber, J.B.; Stage, F.K.; King, J.; Nora, A.; Barlow, E.A. Reporting structural equation modeling and confirmatory factor analysis results: A review. J. Educ. Res. 2006, 99, 323-338. [CrossRef]

88. Pihlström, M.; Brush, G.J. Comparing the perceived value of information and entertainment mobile services. Psychol. Mark. 2008, 25, 732-755. [CrossRef]

89. Chang, C.C.; Hung, S.W.; Cheng, M.J.; Wu, C.Y. Exploring the intention to continue using social networking sites: The case of Facebook. Technol. Forecast. Soc. Chang. 2015, 95, 48-56. [CrossRef]

90. Mouakket, S. Factors influencing continuance intention to use social network sites: The Facebook case. Comput. Hum. Behav. 2015, 53, 102-110. [CrossRef]

91. Kowalewski, S.; Ziefle, M.; Ziegeldorf, H.; Wehrle, K. Like us on Facebook!-Analyzing User Preferences Regarding Privacy Settings in Germany. Procedia Manuf. 2015, 3, 815-822. [CrossRef] 